and this has led to very contradictory opinions. "Although, looked at superficially, my statistıcs are rather less favourable to the marriage of first cousins than are those of many other observers, I am strongly of opinion that, having regard to the remarkable antecedent neurotic history of the first cousins who have married and procreated feeble-minded children, the evil apparently resulting is, that where there is hereditary predisposition, the intermarriage of relations determines the concurrence of two morbid factors, and this may account for the undoubted greater frequency of feebleminded children among the progeny of cousins than among those of mixed marriages."

Illegitimacy might be a potent factor in the causation if it entailed emotional disturbance in the mother during pregnancy. Attempted abortion might also have an influence. Idrocy is occasionally induced by deprivation of the senses. The case of a boy who was born only with the sense of smell and that of touch was narrated. The boy could "smell out" his friends, and manifested by a smile his consciousness of their proximity.

Cretinism might be caused by malarial poison. Some cases under Dr. Down's care were procreated during the intemperance of the father. Three of Dr. Down's cases of cretinism were males, and nine were females. He gave a résumé of the work of Billarger (1857), Dr. Hilton Fagge, Sir William Gull, Dr. Ord, Professor Kocher, and Victor Horsley on th $\mathrm{e}_{\mathrm{e}}$ relationship of cretinism to myxoedema and the thyroid $g$ and.

Dr. Down e ntertains positive opinions as to the higher culture of wom en. He says: "If there is one thing more certain than another about the production of idiocy, it is the danger which arises from the culture of only one side of woman's nature. ..... There can be no reason why the faculties which they possess should not be cultivated so as to make them not only fit to be 'mothers of men,' but also companions and helpers. My statistics point to the importance of training our sons to be temperate, and our daughters to be self-possessed."

\section{THE WHITE CORPUSCLE OF THE BLOOD.}

A SUPPLEMENT TO MY REMONSTRANCE ADDRESSED TO PROFESSORS OF PHYSIOLOGY AND PATHOLOGY AGAINST TEACHING, IN THEIR WRITINGS, LECTURES, OR OCCASIONAI ORATIONS, THAT WHITE CORPUSCLES OF THE BLOOD EMIGRATE FROM THE INTERIOR OF SMALI VRSSELS, UNTIL THEY HAVR VERIFIED IT BY ACTUAL OBSERYATIGN OF THEIR OWN AS A FACT IN NATURE.

\section{BY T. WHARTON JONES, F.R.C.S., F.R.S.}

Trovar he still held that white corpuscles do emigrate through the walls of small vessels from the blood therein contained, Cohnheim latterly came to the conclusion that the escape depends on a passive filtration merely, and not, as he first supposed, on an active boring by means of processes which he alleged the white corpuscles shoot out even while the blood is still within the living vessels, in the amoboid manner they are seen to do in blood displayed under the microscope immediately that it is drawn.

Dr. Binz of Bonn, ${ }^{1}$ however, maintains the validity of Cohnheim's first teaching, and, in support of it, adduces an experiment by which he thinks the white corpuscles of the blood within the vessels of the living part under observation can be rendered incapable of undergoing amœboid change of shape, and incapable therefore, according to him, of boring a passage through the vascular walls, so that emigration is prevented. This seems to be an inconclusive experiment, seeing that a reagent which could extinguish the irritability of white corpuscles is not likely to leave unscathed the other constituents of the blood and the integrity of the vascular walls. Suspension of the alleged capacity of white corpuscles to shoot out processes in an amceboid manner while the blood is still within the vessels might thus be owing to a change in the condition of their surroundings, as much as to change in that of the white corpuscles themselves. But, let it be asked, did Dr. Binz ever really see white corpuscles of blood, while still within the living vessels, shoot out processes in an amoboid manner under any circumstances, and by a teredinous action therewith make their way through the vascular walls?

Even if white corpuscles of the blood while still within the living vessels did undergo amoboid change of shape, what grounds are there for the supposition that the diverticular processes they shoot out do or could exert any boring action? The idea of a boring action, in fact, betrays an imperfect study of the nature of the amoeboid phenomenon exhibited by the white corpuscles in blood newly drawn. The amoboid change of shape which the white corpuscles commence to undergo in blood immediattly on being drawn seems to be really the result of partial coutraction or collapse of the cell wall around the nucleus and contained protoplasm on one side, whilst on another side the wall is protruded here and there in diverticula. This takes place with a more or less evident jerk, and has been mistaken for an actual bursting of the corpuscle with evacuation of its contained protoplasm. There is, bowever, no such bursting of the corpuscle nor evacuation of th protoplasm. ${ }^{2}$ Continuing to watch the corpuscle in its supposed burst state, we may see a diverticular process become more or less retracted in concurrence with a supervening diverticular protrusion of some other part of the cell wall which had been previously collapsed around the nucleus and protoplasm. Of the nucleus any defined view is prevented by the protoplasm.

The protrusion of a diverticular process is thus certainly not an active movement with force, like that of a proboscis fitted for a boring operation, as supposed. The phenomenon appears to be a last manifestation of the vital irritability inherent in the substance of the white corpuscles, excited by the altered condition in which the blood comes to be placed by abstraction from the living body. After the fibrin of the blond under examination is seen to have become deposited on the slide by coagulation from the plasma, the serum that is left seems to be received into the interior of the collapsed white corpuscles by endosmotic imbibition through their wall into the more consistent protoplasm, and distends them so far that they recover in some degree their round form.

In the course of our observations of the flow of blood in the vessels of a frog's web displayed under the microscope, a white corpuscle may often be seen to become adherent by a point of its surface to the wall of a vessel, and to be presste into a pear shape, in consequence of the bearing of the passing stream on it while thus anchored. When the adhesion gives way, the white corpuscle, on becoming fre, recovers its previous round form, and is carried along in the stream. This phenomenon, which is of well-known occurrence and obviously passive, has actunlly been described as a manifestation of an active nibbling on the part of the corpuscle by means of a process which it shoots out as a feeler for the purpose of finding a pore in the wall of the vessel through which to commence a boring operation in order to emigrate.

It is well known that when the white corpuscles of the blood are acted on by much diluted acetic acid, the protoplasm is dissolved out, and an object like several smal nuclei adhering together brought into view. This object is commonly accepted as the vera effigies of what actually exists in nature before the abstraction of the protoplasm permits it to be seen. In my paper on the "Bloodcorpuscle," in the Philosophical Transactions for 1846, it was, however, shown that the white corpuscle possesses in reality only one large nucleus, and that the appearance of several small ones aggregated together is owing to a corrugation of the cell wall of this single large nucleus by the action of the acetic acid of the dilution commonly employed. To prove that such is the fact, let, water acidulated in the slightest degree only be used. Under the action of this, solution of the protoplasm will go on, though very slowly; but if we patiently watch its progress, a nucleus-single and large-will at last come into view. ${ }^{3}$

The protoplasm evacuated, as alleged, from the burst corpuscle was supposed to act as a ferment whereby coagulation of the blood was induced, but in disproof of this opinion there stands the fact that in the conrse of our observation fibrin is deposited by coagulation on the glass slide, though no such bursting of the corpuscles or evacuation of their contents is seen to take place.

3 In histnlogical research. reagents applied to the object under microscopical examination are often of great assistance by bringing into view details of structure and indicating chemical composition. As above shown, however, acetic acid corrugates the single large nucleus of the white corpuscle sh as to make it appear as an aggregation of several small ones. From this example, a caution must be interposed agains accepting the appearances disclosed by the action of reagents on tissues 
In the course of my researches, I observed that the single nucleus of the white corpuscle of horse's and elephant's blood in particular was less susceptible of becoming corrugated under the action of acetic acid. Here I would particularly remark that the single nucleus of the white corpuscle of the blood of man and the mammifera corresponds in size and structure with the red corpuscle of the same blood; being, for example, very large in the elephant, in the blood of which the red corpuscles are very large; and, on the other hand, very small in the goat, in the blood of which the red corpuscles are very small; furthermore, inclining to an oval form in the alpaca, the red corpuscles in the blood of which are oval. It was for this reason, among others, that in my papers on the "Blood-corpuscle," in the Philosophical Transactions for 1846 , I enunciated the view that the red corpuscles of the blood of the mammifera are homologous with the single nucleus of their white corpuscles. ${ }^{4}$

To return to the question of "emigratio." Although Cohnheim latterly abandoned the idea that emigration of white corpuscles from the blood is an active process, I do not know whether he continued to hold that white corpuscles, having passively escaped by filtration, do then commence to undergo amoeboid movements, and thereby wander in the interstices of the tissues. If a minute section of the cornea be displayed under a microscope with a one-eighth of an inch object-glass, and attentively examined, no corneal corpuscles are at first seen at the cut edge. After a brief interval of time, however, corpuscles are observed to protrude as if filtering through interstices. Are these corneal corpuscles the objects which Cohnheim considered to be white corpuscles of the blood which had emigrated through the walls of vessels in the adjacent part of the conjunctiva and sclerotica, and which had, as he supposed, made their way by mears of amoboid movements into the interstices of the cornea?

The gist of Cohnheim's doctrine, we have above seen. is that "emigratio" of white blood-corpuscles constitutes the first real characteristic step of the inflammatory process. The question, therefore, latterly agitated between Cohnheim and Binz as to whether emigration be a passive filtration or an active boring would be so far of secondary import in the pathology of inflammation, even if emigration pure and simple could be demonstrated. We have seen that "emigratio" has been accepted and taught as a fact by professors who seem never to have made any observation of their own relating to the subject. In the Hunterian oration at the Royal College of Surgeons some two years ago, the orator, in referring to John Hunter's sketch of the phenomena of inflammation, observed that if his hero had flourished in the present day he would have dwelt in a particular manner on the emigration of white blood-corpuscles, by virtue of their amobiform endowmente, through the softened walls of the small vessels and their further action on the tissues. Hunter, I am sure, would have done no such thing, but would have first said: "Let us see whether it be a fact that white corpuscles do emigrate at all, as alleged." Had the orator himself ever done this? Pity that some guardian angel had not roused him from the musings by which he was led to make such a suggestion, and whispered into his ear: nil fingendum, nil excogitandum, sed inveniendum quod natura faciat-quod natura ferat. That the walls of the vessels through which emigration is alleged to take place first become softened by inflammation, so that the white corpuscles are enabled readily to bore their way through, is an assertion in which the sequence of the steps formulated by Cohnheim is inverted, so that the gist of his doctrine of the inflam-

as an exact representation of the details of structure actually existing ill nature. Prepared structures mounted on slides-such as sections, varcular injections, \&c.-are for the most part mere toys. It must always be borne in mind that the dissection of minute objects by manipulating under the simple microseope, whether for further examination with a higher power under the compound mieroscope or not.cin never besuperseded by the examination of ready-made specimens mounted on slides.

4 It is to le remembered that the large nucleated red corpuscles of the early mammiferous embryo are homologous with the nucleated red corpuseles of the oviparous vert,brata. See my patpers referred to for details in regard to this and my discovery of large nucleateil corpuscles in the blood of grown mammif era, f snecially the horse and elephant, some with the cell wallslightly tinged rech, and some with the cell wall wholly uncoloured and as pale nearly as the almost invisible cell wall of certain oval nucleated corpuscles (the nuclei very strongly marked) observable in the blood of the frog. which I descriled and delineated forty late years been "rediscovered"-to adopt a euphemism. matory process is misrepresented; whilst his relinquishment of the idea of an active boring operation which he originally eutertained is not mentioned.

"Softening by inflammation," which Mr. Marshall, in his IIunterian Uration under notice, alleged to be a state of the walls of the vessels which permits of a boring of the white corpuscles therethrough, is a mere gratuitous assumption, and, as we see, inconsistent with Cohnheim's teaching. The expression "softened by intlammation" might, however, be admitted as applicable to the softening and disintegration of structure to actual disappearance of the vascular walle, as originally observed and described by myself in cases of intense inflammation of the frog's web, whereby white corpuscles were left free and unenclosed in any wall, but forming, by their aggregation, succedaneous walls of a venous channel, through which the blood was seen still flowing. This observation was quoted in my "Remonstrance" from my essay in Guy's Hospital Reports for October, 1850. Had Mr. Marshall read this?

The characteristic which especially distinguished John Hunter as a scientific man was his subjecting the physiological and pathological questions that came before him to the test of observation and experiment. The suggestion, therefore, that he would have dwelt, on "emigratio" in elucidation of the question of the pathology of inflammation on the mere assumption that it was a tact, made by $\mathbf{M r}$. Marshall in his oration, was like putting in a plea for Cobnheim's doctrine (though at the same time misrepresenting it) under the sanction of John Hunter's name. Such a suggestion, however, was disparaging rather than eulogistic of the hero of the day, and may be compared, conversely, to the divided eulogy of Harvey on the occasion of the unveiling of his statue at liolkestone in 1880, when Mr. (now Sir Richard) Owen, taking advantage of his position as inaugural orator, virtually claimed a place on Harvey's pedestal for the glorification of John Hunter also--a proceeding something like the cunning manœurre of Richie Moniplies (subsequently dubbed "Sir Richard") in Sir Walter Scott's novel of the "Fortunes of Nigel," who enclosed in his master's petition to King James 1., which he had been sent to deliver, a "sifllication" of his own.

The scepticism as to "emigratio" being a fact in rature evinced in my "Remonstrance" on the question has been called "comical"; perhaps the strictures now made may be accounted "pragmatical," though (to adopt Bishop Bedell's aspiration) I hope good men will not so account them. Hereto may be added, now I think of it, that my volume containing two lectures against the Darwinian hypothesis of evolution, which had been delivered in the botanical theatre of University College to large audiences of ladies and gentlemen, was noticed in the Saturday Review at the time of publication in the following words, and no more: "The author is angry, and it is not very scientific to be angry." This short and easy criticism--this shirking the question under review and levelling a flippant personality against the author-was an ignoratio elenchi, aggravated in its meanness and dishonesty by being anonymous.

Ventnor, Isle of Wight.

\section{ON A CASE OF EMPYEMA,}

WITI MUMARKS ON THE MANTER IN WIICII PJIRTORATMON OF 1 BRONCHES IS BROUGHT IBOTT.

BY C. J. BOXD, F.R.C.S.,

HONORARY SURGEOY TO THE LHICESTER IXFILMARY.

Is making a post-mortem examination some time ago in the case of a young man who had clied suddenly with symptoms of empyema clischarging through the lumg, the condition foumd was sufliciently interesting to surgerst the following remarks.

A. B-, a previonsly lealthy lack, aged fourteen, was aclmitted into thes hospital with a history of an attack of pleurisy, with effusion, of sulden onset, and of a month's duration. Some onuces of clanr fluid were dawn off by aspiration. A week later, lowwerer, the patient was seized

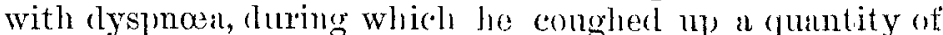
thin, purulent fluicl. The pleural effusion hal, in fact,

${ }^{5}$ Evolution of tho IIuman Race from Apes, and of Apes from Lower Animals - a Doctrine unsanctioued by Science. London, 1876. 